\title{
Implementation of Communication Among the Divorced Women on Remarriage in Indonesia
}

\author{
Novi Andayani Praptiningsih \\ Department of Communication \\ Prof. Dr. Hamka Muhammadiyah \\ University \\ Jakarta, Indonesia \\ noviap1711@gmail.com
}

\author{
Heny Hayat \\ Department of Communication \\ Prof. Dr. Hamka Muhammadiyah \\ University \\ Jakarta, Indonesia
}

\author{
Silvira Yolanda \\ Department of Communication \\ Prof. Dr. Hamka Muhammadiyah \\ University \\ Jakarta, Indonesia
}

\begin{abstract}
This research aims to know the construction of social reality, which can be understood from the reasons, motives, and the concept itself the subject researched. Researchers using qualitative research methods with the phenomenological approach, i.e. an approach in how the world experiences the perpetrator with the epistemological assumptions based on that fact is what is in the shadow of the perpetrator. This research is the paradigm of constructivist view human experience consists of many means of reproduction of reality and not reality. Phenomenology is not just classifies every conscious action being performed, but also includes the prediction of the Act in the future, as seen from the aspects associated with it. It all stems from how does one interpret the objects experiences. The subject of research 5 (five) persons aged between 30-48 years who are domiciled in Jakarta and Bandung, the old widow with one, three, five, nine and 12 years. The results showed that: 1) construction of reality according to female perpetrators of remarriage after divorce include processes that reveal the reasons, motives, and the concept of self they have with respect to the choice of his life. From the results of the study found that the subject decided to remarry after a divorce because of religious reasons, biological, economic, and social. While the motive was oriented towards the past and the future so the self-concept is formed in the early days after the divorce was a negative self-concept and positive self concept began to take shape when they decided to remarry after divorce; 2) The communication process for women perpetrators of remarriage after divorce in a family with his new adaptation takes quite a long time for mutual understanding of each other. The process of adjusting the self encountered many communication barriers. Stillness and avoid impressed demonstrated by research subject when there are things that interfere with their feelings in a relationship with a new family. But in the end they realize that adaptation is done must be supported by a communications open to reveal all the problems encountered in order to find the solution, which in the end can find joy in wading through the dipper households.
\end{abstract}

Keywords - Implementation, Communication, Divorced, Remarriage

\section{INTRODUCTION}

A marriage cannot last forever until divorce occurs as a last resort for some people. At present, divorce is no longer seen as a shameful thing, even though Allah hates it. In some studies shows that the tendency of divorce claims is mostly done by women. This can be caused by a spouse or woman who makes a divorce to see divorce as a solution to overcome the problems that arise in marriage that can not be overcome by the two partners. Even so, divorce is often interpreted as a failure experienced by a family, as well as a disgrace for the extended family of both parties.

On the one hand, divorcing individuals can be free from pressure, reduce inner conflicts experienced during marriage and open up opportunities to build a new, better life. On the other hand, divorce also has consequences in the form of the emergence of post-divorce problems such as economic problems, psychological problems, social problems, childcare problems, sexual problems, and the problem of changes in self-concept. With a new status as a widow especially those who have children, women must act as single parents and must be able to regulate the family economy independently. As a single parent, women must be able to play a dual role, namely as a father whose function is to earn a living and as a mother who plays a role in educating children.

Some reasons that encourage individuals to remarry are to get love and friendship, fulfill biological needs, economic / financial needs, ethics, morals, and social norms, factors of children's education, and to obtain social status. If the remarriage behavior is considered a negative behavior for some people, then this view is not a misconception but a thought that sees women as post-divorce remarriage actors from an outsider's point of view (ethical view), as a fact, not an emic view (how do women do remarriage see their own lives).

Based on the description above, there are two questions as the problem of this research: How do post-divorce remarriage women construct their social reality in their own view, which includes the reasons, motives, and self-concept they have regarding their life choices? And what is the process of communicating women's post-divorce remarriage in an adaptation to their new family.

\section{THEORETICAL REVIEW}

\section{A. Max Weber's Theory of Social Action (Social Act)}

Weber defines social action as all human behavior when and to the extent that the individual gives a subjective meaning to the behavior. Actions here can be open or hidden, can be a positive intervention in a situation or intentionally remain silent as a sign of agreement in the situation. For Weber, it is clear that human actions are basically meaningful, involving interpretation, thinking and intentionality. Society is an active entity consisting of people thinking and doing meaningful social actions. Their behavior is only part of their overall behavior. The consequence is that the natural sciences approach is not suitable for studying individual behavior that is socially meaningful, because the natural sciences approach 
only considers the visible phenomena, but ignores hidden forces that move people, such as emotions, ideas, intentions, motives, feelings, determination and so on (Mulyana, 2006: $61)$.

\section{B. The theory of Phenomenology Alfred Schutz}

According to Schutz, humans construct meaning outside the mainstream of experience through a "typification" process. Relations between meanings are organized through this process, or commonly called stock of knowledge. So the collection of knowledge has practical uses of the world itself, not just knowledge of the world. The core of Schutz's thinking is how to understand social action through interpretation. The interpretation process can be used to clarify or examine the true meaning, so that it can provide the concept of implicit sensitivity. Schutz places human nature in subjective experience, especially when taking action and taking attitudes towards the world of everyday life. It is through this typification that humans learn to adapt to the wider world, by also seeing ourselves as people who play roles in typical situations. These social relations between humans then form the totality of society.

\section{Construction Theory of the Social Realities of Peter Berger and Thomas Luckman}

Berger considers social reality to exist by itself and that the structure of the social world depends on humans being the subject. Together with Thomas Luckmann, Berger expressed his thoughts on social construction in a book called The Social Construction of Reality, which states that a person living in his life develops a repetitive behavior, which they call "habits". This habit allows a person to overcome a situation automatically. In the situation of interpersonal communication, the participants ("actors" according to Schutz) observe each other and respond to the habits of others, and in this way all participants can anticipate and rely on the habits of others. Because of this habit, one can build communication with other people that is adapted to the types of people, which is called typication. Over time, the next reality, some habits became the common property of all members of the community, then an institution was formed. Institutions allow the development of a role, or a collection of habitual behaviors associated with the expectations of individuals involved.

\section{Theory of Symbolic Interaction of George Herbert Mead}

Mead assumes that social reality is a symbolic interaction of individuals within it. Mead sees the mind (mind) and self (self) as part of human behavior, which is the part of their interaction with others. Self-concept (self consept) is an important part in every talk about the human personality. Selfconcept is formed and can change due to interaction with the environment. Self-concept owned by individuals can be known through information, opinions, and evaluations or evaluation of others. According to Mead, the body is not self and only becomes self when the mind has developed. There are three premises built into symbolic interactions, namely: 1 . Humans act on something based on the meanings that exist for them. 2. The meaning comes from "social interaction with someone else". 3. The meanings are perfected during the process of social interaction. (Kuswarrno, 2009: 113).

Symbolic interactionism contains the core of the general rationale for communication and society. Jerome Manis and
Bernard Meltzer separate seven fundamental theoretical and methodological things from symbolic interactionism, namely:

1) People can understand things by learning from experience. A person's perception is always translated into symbols.

2) People can understand things by learning from experience. A person's perception is always translated into symbols.

3) Various meanings are learned through interaction between people. The meaning arises from the exchange of symbols in social groups.

4) All social structures and institutions are created from the interaction between people.

5) A person's behavior is not easily determined by past events, but also intentionally.

6) The mind consists of internal conversations that reflect the interactions that have taken place between someone and others.

7) Behavior is formed or created within social groups during the interaction process. We cannot understand an individual's experience by observing his behavior. Experience and understanding of various things must also be known with certainty.

\section{E. Research Thinking Framework}

Phenomenology Theory of Alfred Schutz (1899-1959), in The Phenomenology of Social World (1967: 7), suggests that people actively interpret their experiences by giving signs and meanings about what they see. Interpretation is an active process in marking and interpreting something that is observed, such as reading, actions or situations or even any experience. According to Schutz, phenomenology is the study of knowledge that comes from awareness or the way we understand an object or event through conscious experience of the object or event. A phenomenon is the appearance of an object, event or condition in one's perception, so it is subjective. For Shultz and the understanding of phenomenologists, the main task of phenomenological analysis is to reconstruct the world of "real" human life in their own natural form. The reality of the world is intersubjective in the sense that as members of society share basic perceptions of the world that they internalize through socialization and enable them to interact (Mulyana, 2008: 63).

The application of this theory in this study is that women of remarriage after divorce interact using symbols that contain signs, signs and words in interpreting the reality of the decision to remarry. Here is a picture of the research flow of the Construction of the Reality of the Performers of PostDivorce Remarriage in Jakarta and Bandung. The theory of Social Action from Max Weber overshadows the theory of Phenomenology (Alfred Schutz) and the Symbolic Interaction theory (George Herbert Mead and Herbert Blumer). The Phenomenology Theory sees that people actively interpret their experiences by giving signs and meanings about what they experience in this case are women in Bandung and Jakarta on remarriage behavior after divorce. While the Symbolic Interaction theory sees individuals interacting by using symbols which contain signs, signs and words in interpreting their own experiences, including when 
communicating with other family members, for example with a new partner and extended family.

\section{METHODOLOGY}

\section{A. Research Paradigm}

The research paradigm is interpretive constructivism. In accordance with ontological assumptions, reality is regarded as a relative social construction of truth. Epistemologically, there is an interaction between the researcher and the subject under study. Meanwhile, from an axiological perspective, researchers will treat values, ethics and moral choices as an integral part of research.

\section{B. Research Subject}

The subjects in this study were five women of remarriage after divorce, who were interviewed as key informants, with widows of one, three, five, nine and 12 years respectively. 3.3. Data collection technique Data collection techniques are in-depth interviews or in-depth interviews. Indepth interviews are data collection techniques by way of face-to-face verbal exchange conducted by an interviewer on research subjects. Face-to-face meetings are repeated between researchers and research subjects. In addition, researchers also conduct literature studies that are used to find concepts and theoretical basis used.

\section{Data Collection Technique}

According to Engkus Kuswarno, in-depth interviews are interviews that do not have a predetermined alternative response or better known as an unstructured interview. This type of interview encourages research subjects to define themselves and their environment, for use their own terms about the object of research (Kuswarno, 2008: 54). Regarding confidentiality and protecting the privacy of informants, there are signs that monitor the research process, namely research ethics. One of the principles of research ethics that researchers must pay attention to is respecting the privacy and confidentiality of research subjects (respect for privacy and confidentality). Research is an effort to dig up information, ins and outs of events or build opinions on a situation or event. In a social context, data relates to someone, institution or organization that is attached to the data extracted. Scientific research is natural and should conceal identity for respect. Text, images, even ornaments that show an identity, should be hidden" (Bajari, 2015). Therefore, researchers must maintain the confidentiality of informants by hiding the real names and identities of the informants.

Patricia Adler and Peter Adler refer to two main principles that characterize observational techniques in the qualitative tradition. First, qualitative observers must not interfere in the affairs of research subjects. Second, qualitative observers must maintain the natural side of the research subject (Denzin \& Lincoln, 2009: 496). During the data collection process, the researcher is free to attend any routine good activities or incidental events organized by Arus Pelangi. To establish closeness and instill the confidence of informants in researchers, researchers are egalitarian and create a conducive atmosphere with informants. There are several techniques used in observation, as follows:

1) Eavesdropping techniques, which are any listening techniques that can be heard without having to ask the research subject to talk about it.
2) Tracer technique, which follows the research subject related to various activities carried out within a certain period of time.

3) Senitizing concept, which is the self-esteem of the researcher, by striving to be able to enter the object of research by directing observations to all things found in the field, for example by being egalitarian and thinking "out of the box".

According to Burhan Bungin, Focus Group Discussion (FGD) is a data collection technique that is generally carried out on qualitative research to obtain data from a group based on the results of discussions centered on a particular problem. This technique is used to avoid the wrong meaning of a researcher because of the encouragement of the subjectivity of the researcher (Bungin, 2003: 178). There are no right or wrong answers from the participants, because they are free to answer, comment, or argue (positive or negative) as long as the discussion problems (Kriyantono, 2010: 120) 4. Review the Document Documents as data sources can be used to test, interpret, even to predict (Moleong, 2000: 161). According to Scatman and Strauss, historical documents are an important ingredient in qualitative research.

As part of the field method (field method), researchers can trace historical documents and other secondary sources (Mulyana, 2009: 196). 3.4. Data Analysis Techniques Data analysis techniques in this study were prepared by adopting qualitative data analysis techniques developed by Miles and Huberman namely interactive model analysis (interactive model of analysis). In line with the aforementioned Bogdan, Miles \& Huberman (in Denzin \& Lincoln, 2011: 592) said that this interactive model focuses on three components, namely: data presentation data reduction, drawing conclusions / verification involving the process of interpretation of the researcher through the process negotiation / consensus between subjects and discussion with colleagues.

In collecting data through interviews, steps or procedures are taken which include asking, interpreting, concluding, examining, and verifying. The researcher asks a question, when the research subject gives the answer, the researcher listens analytically. After that the researcher interprets, draws conclusions, and makes an inspection note to verify, either in the form of probing or crosscheck. Technically, data collection can be assisted by recording devices, such as tape recorders. However, to avoid technical mistakes, such as not being recorded, the researcher also makes interview notes, so that they still have written data.

\section{Data Analysis Technique}

The data in this study using interactive model data analysis Miles and Huberman (in Islami, 2001) that there are three processes that take place interactively. First, data reduction, namely the process of selecting, focusing, simplifying, and abstracting data from various data sources, for example from field notes, documents, archives and so on. Then the process of reinforcing, shortening, removing unnecessary, determining focus and managing data so that conclusions can be made. Second, the presentation of data, such as assembling data and presenting it well so that it is easier to understand. Third, draw conclusions / verification. Verification is obtained through the process of negotiation / consensus between subjects, discussing with colleagues, checking data between members. 


\section{E. Data Validity Check Techniques (Data Validation)}

Establishing data validity (trustworthiness) requires inspection techniques (Moleong, 2004: 121). Examination or testing of the validity of the data in qualitative research is carried out using four criteria, namely: credibility, transferability, dependability, and confirmability. To support credibility, researchers will try to study the social and cultural situation in the informant's environment. What researchers do is: 1) Talking with other people (peer debriefing). 2) Triangulation, in three ways, namely: Source Triangulation, Technical Triangulation, Time Triangulation. 3) Member check (Sugiyono, 2005:11).

\section{RESULTS AND DISCUSSION}

\section{A. Research Subject Profile}

Martini (Bandung). The first subject was named Martini who worked as a kindergarten teacher. The 48-year-old subject who was undergoing his second marriage after divorcing from the first husband in 1999 ago. He decided to remarry 5 years later after his divorce. From his first marriage, he was blessed with a son who currently lives apart because he has a family. His second marriage in 2004 with one widower. The man who works as a teacher is 5 years older than him. Different from the first husband whose age difference was only 2 years. From the second marriage, Martini was blessed with a daughter and a son who are currently 7 and 4 years old respectively.

Euis Qodariah (Bandung). The second subject was Euis Qodariah. The woman born in Bandung on October 12, 1975 was a housewife who also worked in a textile factory in her hometown. His first marriage took place when he was a student. Similarly, the first husband at that time was also a student at a private university in the city of Bandung. Their decision to marry at a young age and economic conditions have not been established because they want to avoid problems that the family does not want. The first marriage in 1997 was blessed with two daughters, aged 14 and 11 respectively. The tempest of the household began to appear before the birth of the second child. The decision to divorce was finally taken a year later, precisely in 2002. In the same year he met a working man who was single. The man who was born in 1968 finally proposed to the subject in 2003. The second marriage of the subject lived to this day and has been blessed with 2 children, women and men, who are currently 8 years and 3 years old respectively.

Endang Sumiati (Bandung). The third subject was Endang Sumiati, a housewife with two children from the first marriage and both. The woman born in Sukabumi on June 20, 1982, waded through the household ark with her first husband for 5 years and was blessed with a daughter who is now 8 years old. Precisely he married in 2002 and decided to divorce in 2007. The decision to remarry was taken a subject three years after the divorce in 2010 was just blessed with a daughter who was 1 year old. The second husband is a man who works for a motorcycle dealer.

Nita Manoppo (Jakarta). The fourth subject named Nita Manoppo. The daily activities of a woman born in Manado on August 27, 1967 as a lecturer at a private university in Jakarta. His first marriage was done without the blessing of his parents, and apparently his ex-husband was very temperamental, jealous, and often committed domestic violence. One of the reasons for their household rift is because Nita never gets pregnant. When divorced, Nita is a widow without children. After nine years of widows, Nita finally found the port of her heart, a widower who had two children. Meetings occur when they attend a seminar. Currently Nita is pregnant. His second husband worked as a reporter for a private television in Jakarta, and had a significant position.

Ajeng Sekarningrum (Jakarta). The fifth subject was a Javanese woman who was a doctor at a government hospital in Jakarta, Ajeng Sekarningrum. The first female marriage born in Yogyakarta, April 15, 1966 lasted only three years. Ajeng has one son who is now studying at a state university in Depok. Her ex-husband who is also a doctor at the same hospital, remarried to a nurse, shortly after they divorced. Ajeng widowed for a long time because it was difficult to get rid of trauma after divorce, so it was very long to shut down and organize your heart. But finally Ajeng fostered a household dug out four years ago with a widower who had one daughter who was the same age as Ajeng's son. Ajeng's second husband works as a consultant and trainer in several companies. Currently they are living with their children in luxury housing in BSD.

\section{B. Social Construction of Women Post-Divorce Remarriage Actors}

The second marriage has two missions, namely fostering close relationships with partners while establishing emotional closeness with children, both between parents and their children (stepchildren and biological children). Thus the personality qualities of both parents determine whether a second marriage can be lived smoothly or not. In terms of fulfilling biological factors, remarriage is considered the best way to legitimately distribute sexual needs with a new life partner especially for individuals who are still in their reproductive age. So that individuals can meet their biological needs while still fulfilling social norms. This was confirmed by the research subject, Endang Sumiati (30 years old) who had the experience of marriage at the age of 20 for his first marriage. The following is the story:

"Many people if asked why they remarried this reason is the reason, Ma'am. If I am ... because I do not want to fall into a relationship that is forbidden by religion because I cannot withstand that one desire. Sex ... I mean. I am still young Ma'am ... for that one business, I think that is not something we should cover up. I think it's really humane, rather than us wrongly getting along we better marry again to channel it legally with our partner. No sin, ma'am. (Interview, July 11, 2018).

In addition, someone decides to remarry after divorce because he is faced with social problems. The subject named Martini, who is now 37 years old, experienced social problems after his divorce in 1999. Her widow lived for 5 years until she decided to marry in 2004. Here's the reason:

"I survived with my first marriage for 10 years. After divorce, I felt a lot of change in my life. One of them is my relationship with friends and family whose status is married. When I was divorced, they were always there for me. But over time I felt them getting further away, Ma'am. They have not invited me again in the family gathering, my friends who are still intact in their household have also rarely invited to gather. 
I think they are afraid that her husband is close to widows like me. Right, you know, I can't stand that negative assumption. Sometimes if I am walking alone, I see a gaze that is less good than people. One thing that also makes me stressed and depressed. People always ask, when are you married again. Tired of listening to you "(Interview, July 12, 2018)

Someone also chooses to remarry to meet economic needs both for themselves and for their children. In addition, individuals who have children from previous marriages will get help in managing, maintaining or educating their children. This was revealed by the subject Endang Sumiati who had a child from his first marriage. The reason he stated was as follows:

"I really have one child, Ma'am. Maybe people think that one child doesn't make it difficult. Yeah ... if his mother has a permanent job. How about like me? Employment is not clear, income is also not always sure to be difficult, Ma'am. Not the grandiose things I want from the next marriage, at least there are friends sharing in terms of foraging. No need for important civil servants to work and sincerely finance me and my child. Frankly, Ma'am. My first ex-husband had no more news. Where does he remember his son, Ma'am. "(Interview, June 17,2018)

Based on the interview quote with the subject, it shows that there are difficulties faced by someone after a divorce occurs. Financially divorce causes economic difficulties, in this case limited income and finance. The absence of a husband as the family head and breadwinner for the family, a woman must be able to take decisions and take responsibility for herself, including making a living for herself and her children. Unlike the narrative of Nita Manoppo who works as a lecturer, the following is the story:

"I don't have a problem with financial problems, Ma'am. Because I work, and my salary is enough to support myself alone, even I often help my parents, even though they are already well off. So at first I was hesitant to remarry, moreover I had a bad experience, I was afraid of being reprimanded "(Interview, May 17, 2018).

\section{Similar experiences were told by Ajeng:}

"My work demands full concentration, so I don't think of remarrying. Moreover, there is a mere son who always supports me. Alhamdullilah Allah always opens the door for sustenance for me, InsyaAlloh, there has never been a problem with the problem of money. The ex-husband also still finances children's education ”(Interview, July 19, 2018).

From the narration of Nita and Ajeng, because they are career women who are each

have a professional job, then there are no financial constraints for them. However, the decision to remarry after divorce often collides with the bitter experience of previous marital failures. The same thing was revealed by the research subject, the following Martini:

"For 5 years I was a widow, there was no thought of getting married again, because of an unpleasant experience with my previous marriage. But the child is big, I think of old life later. I also think that when my daughter gets married, I want a father who becomes her guardian even though her biological father is still alive or dead, we don't think of it anymore. "(Interview, July 8, 2018)
In the past all things were done and discussed with a partner, but after the divorce everything was done and thought through. This is in accordance with the narration of one divorced woman who was the subject of this study. Endang Sumiati, a 30-year-old woman expressed her desire to remarry because she needs a partner to live life as in the interview quote below:

"At that time the desire to marry again came after I was widowed for 3 years. Initially, I felt strong in my own life, but over time, the feeling of loneliness continued to whack me, especially if I found myself sick, the feeling of wanting to have friends at such a time was mounting. Finally I decided I wanted to get married again because I realized that life was too much to live alone. I need someone who can support each other in terms of spiritual and material, I want to marry again because I need to love someone and need to be loved, Ma'am. At that time there was no target when, I just left with God. (Interview, June 11, 2018)

Many people conclude that marriage is the source of happiness and the highest achievement of life. But it needs to be understood that actually happiness in marriage depends on the parties involved in it (in this case husband and wife) and how they interact with each other in a permanent bond. This is similar to what was revealed by one of the subjects in this study. His usual quiz was called a woman who spent the first marriage for five years until the divorce took place in 2002. It didn't take long for her to decide to remarry a year later in hopes of living a happier life as she said:

"I don't think there is anyone in this world who doesn't want to be happy, Ma'am. The first household failure left grief for me and the children. But I do not want to continue to dissolve in the grief. I also have the right to be happy. Remarrying with a new partner I think is the way for me to be happy. At first I had doubts about myself, especially since the second match came so fast, only one year did I have the status of widow. (Interviews July 9, 2018).

Nita, who in her first marriage often experienced mistreatment (domestic violence) conducted by her exhusband, finally decided to remarry because she wanted to have friends for sharing. The following is the story:

"I am actually afraid when I get married again. I consider him all same, likes to beat and like to oppress. But I just think rationally. I do not have children, in the old days I want to have friends sharing sorrow. Thankfully, God finally gave me one package, husband plus two children "(Interview, July 17, 2018).

But Ajeng's opinion is somewhat different from Nita's, with timid Ajeng stated that they remarried mainly for status, even though Ajeng closed himself and his heart long enough.

"Honestly, Ma'am ... he ... he ... I'm ashamed of talking about it. The reason I remarried because I felt uncomfortable was constantly carrying the status of widow. It's not good, you are a widow. Even though we behave well, still people look negative. Moreover, I work with one hospital with my exhusband, so I still meet often. I'm so uncomfortable, Ma'am. Alhamdulillah, after I remarried, I became more confident, especially if I had to work a team with a former husband who had also remarried for a long time "(Interview, August 19, 2018) 
Based on the answer of the research subject to the reasons and the first motive they encouraged to remarry after divorce, the researcher could discuss it based on the opinion of Alfred Schutz. Schutz agrees with Weber's thoughts on human experience and behavior in the everyday social world as a socially meaningful reality. Schutz calls humans who behave as actors.

The results of interviews with the five subjects of previous research indicate that they consider that remarriage as a solution to adjust after divorce and all the benefits or things that are felt by remarrying foster hope. Hope arises because they want a better change. Individuals who have ever divorced, without seeing how divorce they have experienced certainly have the hope to be able to build a marriage that is better than before.

Hope here the researcher identifies with in-order - motives that refer to the future. Each individual has the ability to form expectations that play a role in directing behavior and includes two aspects, namely the act of anticipation or simple predictions and the demands of someone against others to perform certain actions.

Seeing all the descriptions of the motives and reasons for the post-divorce remarriage women above, researchers can find several categories that describe their self-concept. Reasons can be distinguished from motives. The reason is the first decision to remarry after divorce. While the motive is the urge to continue to take the decision taken. This can be seen in the following categorizations:

Table 1. Categories of Self-Concept of Remarriage Actors based on Reasons and Motives.

\begin{tabular}{|c|c|c|c|}
\hline Reason & Motive & Category & $\begin{array}{l}\text { Self- } \\
\text { Concept }\end{array}$ \\
\hline Religion & & -Term & \\
\hline Economic & & Remarriage & \\
\hline Biological & $\begin{array}{l}\text { Past } \\
\text { Future }\end{array}$ & Middle-term & Nostive \\
\hline Social & & Remarriage & \\
\hline Status & & Long-term Remarriage & \\
\hline
\end{tabular}

From the table above shows that there are four reasons women decide to remarry after divorce. The first reason is biological factors. The subject acknowledged that the need for sex was a reason to remarry as a step to avoid sinning because of the urge of biological needs. While economic reasons are stated by the research subject, which is more due to the economic difficulties they face in supporting children who are the result of the first marriage. Another reason that was also revealed by the subject was to avoid the negative stigma of the people who considered single parent status as a threatening status for their husbands. But the main reason is actually religion, so that it is legal and lawful in the eyes of God.

In the motive category, research subjects basically realized that their household failure in the first marriage was caused by various factors. So that the experience in the past became a benchmark for stepping in and undergoing remarriage after divorce. So that in remarriage they have the hope to get a better life in all walks of life.

At the level of self-concept formed in the subject, there are two, namely negative and positive. Basically the subject is very familiar with themselves as someone who has experienced a failure at the first marriage. They realize that there are many deficiencies in themselves and their exhusbands that are the cause of divorce. Besides that they are also very aware that failure cannot be protracted but they must have confidence in a new partner. So, negative self-concept is formed in the early post-divorce period. But over time this negative self-concept changes to positive when the subject realizes that past failures are not something that must be a barrier to achieving a future with all the better expectations.

The remarriage category that the researcher gave above is based on the length of time the subject is single parent or widowed. The first category is short-term remarriage, namely the decision to remarriage is taken one year after the divorce. While middle-term remarriage is a decision to remarry three years after divorce. The last category is the long-term remarriage is the subject decides to remarry five years after the divorce.

\section{Adaptation Communication for Family Women Acting Remarriage}

Adaptation communication is needed during the adjustment process with their innate spouse or children. The situation will become more complex if the new spouse of the parents brings the child who will later become stepbrother, especially if in the future parents will have or add more children with a new husband (have a new sibling or brother). Conditions like this, in a child, will usually lead to feelings of rivalry because parents who used to only pay attention to themselves, must now share their attention.

"At that time I had two children from the first husband, while my second husband was a single, Ma'am. I was also a little confused at the beginning of our marriage. I feel I have to share my attention to my child and husband. Sometimes if I pay attention to my husband, children feel less cared for. I also feel sorry for my husband, let alone bachelor, Ma'am. The husband was also initially difficult to approach my children. My little child, Ma'am doesn't want to be carried by his stepfather at all. "(Interview, June 9, 2018)

Interviews with research subjects, Euis Qodariah, who has two children from the first husband shows that marriage naturally requires periods of adjustment. The status of "stepparents" attached to them often gets obstacles in building communication with their stepchildren in the early days of marriage. A good relationship between stepparents and children is not only determined by the wishes and efforts of stepparents, but also determined by the readiness of children and child development. Another thing revealed from the interview when parents decide to marry someone else, children usually perceive a second marriage as a loss of love from their biological parents. Children feel compelled to compete with stepparents because biological parents will pay more attention to their new partner. This is a challenge for biological parents to be able to put themselves fairly.

While the experience of other research subjects, Martini, is different again. Her children from the first marriage have difficulty adjusting to their new husband's extended family. This task is felt most heavily because the relationship in the extended family will be more complex by involving siblings and stepbrothers, not to mention the relationship with grandparents. Large family relationships from stepparents tend to be more distant, potentially conflict, and colored 
negative interactions compared to extended families of biological parents.

Unlike the experience of Nita and Ajeng in the process of adaptation with a second husband and their children, both biological children and stepchildren. They claimed that there were no significant obstacles during the process of adjusting to a household's biduk. As revealed by Nita:

"My relationship with my husband and stepchildren is very good. Maybe because I really want to have children. We are like friends, confide in each other. Especially when the husband is overtime or out of town. Because the task of being a journalist makes him spend a lot of time outside the home. But I'm still happy, there are children who accompany at home. In fact they are more open with me than his own father. We often watch in theaters together or have a culinary tour outside the home. That is what I am grateful for ... meaning that I have gained their trust "(Interview, July 17, 2018)

Meanwhile, Ajeng felt he had no problem with the adjustment process between himself, his husband and their innate children. The following is the acknowledgment:

"My son and husband's daughter are very familiar, maybe because they are of the same age. Both are university students. My son looks very busy and nurtures his sister. Husbands also behave not to discriminate between them. Well ... alhamdulillah, Ma'am. Husband is very open, even the smallest things are always discussed with me, sometimes involving children. A situation like this makes me feel valued ... feeling like I'm not"(Interview, June 19, 2018).

Research subjects Endang Sumiati who married a second husband who was 10 years old with him faced a different problem. Problems that arise in the process of adjusting to the new partner are more due to economic conditions. This 30year-old woman does not have a permanent job while her new husband is only an employee at a motorbike dealer. The financial difficulties they often encounter and become the trigger for conflicts such as the decline below:

"In the past ... if at the end of the month my husband often silenced me. He doesn't say anything, Ma'am. I'm also confused about it. It turned out that after I asked, he was so because he thought there were still needs that had not been fulfilled even though our money for that month was low. Worse yet, Ma'am. He often compared his financial condition to his first marriage which was more established because his ex-wife also worked ". (Interview, Juy 11, 2018)

Based on the results of interviews with the subject of the research, it shows that every individual who marries and forms a family will experience a stage of self-adjustment by differences in views, life experiences, rules, and attitudes and behavior. These differences can be a cause of conflict. To form a harmonious family, effective communication is needed, division of roles (tasks) for each family member, as well as good ways to manage and resolve conflicts.

This was acknowledged by the subjects in this study which led to the failure of the first marriage. Family intimacy and resolution of all problems that arise can be achieved by building good communication among existing family members.

"I realized that my previous marriage was full of conflict because my ex and husband were unable to communicate their wishes. Maybe our courtship time is not discussing important things. As a result the first three years were full of bickering until I decided to leave home and get a divorce. I am more prepared with the second marriage and I have opened my husband to sensitive things. " (Interview, June 9, 2018)

From Euis's statement (30 years), it shows that every couple who will remarry has high hopes to be able to build a better household life. Each has proceeded to see the weaknesses of the relationships they built with their previous partners. Armed with this knowledge, they are also quite confident that they can live both households better.

"Former husband I was an accountant. His name is also working in the financial field. He often overtime and must go to the branch office to conduct an audit. I used to be angry and accuse my husband of being selfish. I thought he was too busy with his work and forgot about me and the children. But at that time I rarely said to my husband, I continued to grow up until finally we were noisy. So on ". (Interview, July 8, 2018)

It is clear that we as humans sometimes do not escape mistakes. A person may be upset, angry, and disappointed with the situation. Whoever it is, feeling disappointed or angry is very normal to experience. Various methods are taken to show that feeling. For this one research subject, Endang Sumiati, chose to remain silent when a conflict occurred.

"I used to keep quiet when I was upset. I rarely talk to my husband about what I feel. But my silence did not make the problem be resolved, Ma'am. My goal is, not to be noisy with my husband. (Interview, July 11, 2018)

The results of interviews with the research subjects indicate that communication in the family is the most ideal form of communication. Because the hierarchy between parents and children exists but does not cause communication formalities between them. Differences in cultural background, education, age, habits and personality between family members, especially husband and wife should not be a barrier to communication. Since a pair of people got married, the communication of two extended families began intensively, with the same platform. But in reality, not all families can fulfill the ideal picture of a good family. Today's social, economic and cultural changes have produced many encouraging results and have succeeded in improving the welfare of the community. However, at the same time, these changes have an adverse impact on the family.

\section{CONCLUSION}

Construction of reality according to women post-divorce remarriage includes processes that reveal the reasons, motives, and self-concept they have in relation to their life choices. From the results of the study it was found that subjects decided to remarry after divorce for biological, economic and social / religious reasons. While the motives are oriented in the past and the future so that the self-concept formed in the early post-divorce period is a negative selfconcept and positive self-concept begins to form when they decide to remarry after their divorce.

The communication process of women after divorce remarriage in an adaptation to their new family takes a long time to understand each other. The adjustment process encountered many communication barriers. Silence and 
dodging impressions are shown by research subjects when there are things that interfere with their feelings in relationships with new families. But finally they realize that the adaptation that is done must be supported by open communication to reveal all the problems faced in order to find a solution.

In this study, the author uses data collection techniques by means of in-depth interviews (Indepth Interview). The hope of the author, in the future research should use Focuss Group Discussion (FGD). With FGD, the results of the research are expected to be able to explore the information of the research subjects in more depth. Selection of future research subjects, the authors recommend not only in Java, but also on subjects outside Java. So it is expected that the results of the study will be more varied, because there are differences in local culture, language, habits and custom.

\section{REFERENCES}

[1] Bajari, Atwar dan S. Sahala Tua Saragih. 2011. Komunikasi Kontekstual. Teori dan Praktik Komunikasi Kontemporer. Bandung : Remaja Rosdakarya.

[2] [BKKBN]. Badan Koordinasi Keluarga Berencana Nasional. 1998 Gerakan Keluarga Berencana dan Keluarga Sejahtera. Jakarta: Badan Koordinasi Keluarga Berencana Nasional

[3] Bungin, Burhan. 2001. Metodologi Penelitian Kualitatif. Jakarta : Rajawali Pers.

[4] Cresswell, John W. 1994. Qualitative Inqury and Research Design : Choosing Among Five Tradition. The United State of America : Sage Publications Inc.

[5] Garna, Judistira K. Garna. 1999. Metode Penelitian Pendekatan Kualitatif. Bandung : Primaco Akademika.
[6] Griffin, Em. 2011. A First Look at Communication Theory. Eight Edition. New York : McGraw Hill.

[7] Hamid, Farid dan HerinBudianto. 2011. Ilmu Komunikasi.Sekarang dan Tantangan Masa Depan. Jakarta:Kencana Prenada Media Group.

[8] Miles, M.B., \& Huberman, A.M. 2014. Qualitative Data Analysis : an Expanded

[9] Source Book. Thousant Oaks CA : Sage Publication Inc.

[10] Kuswarno, Engkus. 2009. Metodologi Penelitian Komunikasi, Fenomenologi, Konsepsi, Pedoman dan Contoh Penelitian. Bandung : Widya Padjadjaran.

[11] Liliweri,Alo. 2011. Komunikasi Serba Ada Serba Makna. Jakarta: Kencana Prenada Media Group.

[12] Littlejohn, Stephen W. dan Karen A. Foss. 2011. Teori Komunikasi (Theories of Human Communication). Edisi 9. Jakarta: Salemba Humanika.

[13] Mulyana, Deddy, Solatun. 2007. Metode Penelitian Komunikasi; Contoh-contoh Penelitian Kualitatif dengan Pendekatan Praktis. Bandung : PT. Remaja Rosdakarya.

[14] --------. 2008. Metodologi Penelitian Kualitatif, Paradigma Baru Ilmu

[15] Komunikasi dan Ilmu Sosial Lainnya. Bandung : PT Remaja Rosdakarya.

[16] Rahyono, FX. 2012. Studi Makna, Jakarta : Penaku.

[17] Tim ASPIKOM,2011. Mix Methodology dalam Penelitian Komunikasi. (Dilengkapi dengan Aplikasi Metode Penelitian). Yogyakarta:Buku Litera dan BPC dan ASPIKOM.

[18] Schutz, Alfred, 1967, The Phenomenology of The Social World, Evanston :

[19] Illinois Northwestern University Press.

[20] West,Richard, Turner,Lynn H,2010. Pengantar Teori Komunikasi.Analisis dan

[21] Aplikasi (Introducing Communication Theory:Analysis and Application).edisi 3, Jakarta:Salemba Humanika. 